\title{
Conversa com Paloma Vidal sobre Não Escrever: a performance participando da escrita
}

Katerina Blasques Kaspar ${ }^{1}$

\author{
Sobre o projeto Não Escrevere a metodologia empregada na entrevista
}

EM SETEMBRO DE 2019, TIVE A OCASIÃO DE CONVERSAR COM A ESCRITORA E PROFESSORA UNIVERSITÁRIA PALOMA VIDAL. A conversa foi motivada pelo interesse em refletir sobre seu processo criativo no projeto Não Escrever. O projeto se inicia em 2015, manifestando-se em formatos variados: um projeto acadêmico; uma série de palestras performáticas; um livro cartonero. Meu primeiro contato com seu projeto se deu quando fui espectadora de uma destas palestras performáticas, no espaço de convivência do Sesc Vila Mariana, em outubro de 2017. As palestras performáticas são gestadas dentro do projeto Em Obras ${ }^{2}$, em que um coletivo de mulheres escritoras e artistas realizam apresentações ao público de projetos em curso. $\mathrm{O}$ inacabamento de suas obras e o aspecto de work in progress são destacados nesta prática. O segundo contato com seu projeto foi com a edição de Não Escrever pela Malha Fina Cartonera ${ }^{3}$, editora independente que compõe manualmente os volumes editados, usando materiais como papelão reaproveitado, tintas, colagens de papel e costura manual. As edições são realizadas em oficinas coletivas e cada livro confeccionado resulta em um objeto exclusivo. Notamos que nessas duas manifestações do projeto - palestra performática e livro cartonero - o aspecto do encontro é fundamental. Na primeira, assistimos ao encontro da escritora com seus leitoresespectadores. Na segunda, observamos pessoas interessadas no projeto e na confecção de livros, sujeitos que podem ser considerados potenciais leitores, reunidos com a escritora para realizar o trabalho manual cartonero.

Tanto na ocasião mencionada da palestra performática quanto no livro cartonero ${ }^{4}$ a narrativa foi elaborada em camadas que se entrecruzam. Em uma primeira camada, conhecemos uma pesquisadora que mora em São Paulo e que vai à Paris, acompanhada por seu filho, para estudar o projeto de livro de Roland Barthes, do qual hoje conhecemos apenas oito fólios manuscritos e que se chamaria Vita Nova, mas que ele nunca chegou a escrever (um dos motivos foi sua morte repentina, em 1980). Em outra camada, conhecemos algumas cartas escritas por Barthes à pesquisadora e crítica literária Leyla Perrone-Moisés. Nelas, o francês agradece os vários convites da brasileira para visitar o Brasil e se desculpa reiteradamente ao lamentar sua impossibilidade de realizar a viagem. Aproveitando-se do registro real destas cartas, Vidal apropria-se dessa correspondência, localizando nelas um sonho de viagem e realizando-o ao ficcionalizar como teria sido essa visita de Barthes à São Paulo. Na narrativa, somos convidados a descobrir como teriam sido suas experiências e impressões no país,

\footnotetext{
${ }^{1}$ Mestranda no Programa de Pós-Graduação LETRA (Letras Estrangeiras e Tradução), da Faculdade de Filosofia, Letras e Ciências Humanas da Universidade de São Paulo. Contato: katerina.kaspar@usp.br

${ }^{2}$ Para conhecer as edições dos ciclos de palestras performáticas e acompanhar os trabalhos das participantes, acessar a plataforma do projeto: https://cicloemobras.wordpress.com/.

${ }^{3}$ A editora inspira-se de um projeto iniciado na Argentina, em 2003, que propõe a edição de livros de forma manual e independente, usando materiais em geral marginalizados ou mesmo descartados, processo nomeado de cartonero. Malha Fina Cartonera é responsável pela edição em dezembro de 2018 de Não Escrever. Para conhecer mais sobre o trabalho da editora, acessar a plataforma: https://malhafinacartonera.wordpress.com/.

${ }^{4}$ VIDAL, Paloma. Não escrever. São Paulo: Malha Fina Cartonera, 2018.
} 
vendo-o passear sobretudo pelo bairro da Liberdade. Uma última camada de Não Escrever é narrada pela voz do filho da personagem pesquisadora, em que figuram os temas do medo e do contexto político que assolava o Brasil no conturbado processo de impeachment de 2016.

O objetivo central de nossa conversa era entender como as palestras performáticas participam do processo criativo da escritora e do projeto em questão, Não Escrever, a partir da perspectiva da crítica genética. Para discutir sobre isso, conversamos sobre tópicos que orbitam em torno deste projeto, tais quais a menção de outros de seus projetos (como por exemplo o próprio coletivo do Em Obras); a convivência em sua vida dos ofícios de acadêmica e de escritora; sua relação com a obra de Roland Barthes. Nossa postura metodológica ao longo da entrevista foi a de não interromper excessivamente a fala de Vidal, permitindo-lhe um fluxo mais contínuo de fala e de reflexão. Registrei a conversa em material de áudio e a transcrevi, posteriormente. O resultado consiste em um material com blocos mais extensos de fala da escritora intercalados por perguntas e intervenções breves realizadas por mim. Ao analisar este material, observava que o fluxo de ideias da escritora por vezes estava espiralado, quando ela retomava aspectos que havia mencionado em determinado ponto da conversa para trazer um novo tópico. Tal aspecto, caro à oralidade e à espontaneidade que assumi ao decidir realizar uma conversa com perguntas no estilo aberto, resultaram em um conteúdo com informações um pouco dispersas. Desse modo, no momento da edição, por um lado, houve a preocupação em preservar o caráter da oralidade, mantendo as estruturas das falas o mais próximo possível à transcrição textual bruta do material em áudio. Por outro lado, algumas das falas de Vidal estavam direcionadas para alguém que já conhecia em parte seu trabalho, de modo que compreendi a necessidade, em determinados trechos, de realizar comentários aos blocos de fala da entrevistada. Estes comentários são frutos da análise da transcrição da entrevista e, portanto, escritos posteriormente à ocasião da conversa com Vidal. Além disso, realizei alguns enxertos, marcados com colchetes, para adicionar especificações ou complementos à fala da entrevistada. Neste sentido, o material apresentado a seguir se trata de uma entrevista comentada, em que as falas da entrevistada estão reportadas dentro de comentários elaborados de modo bastante próximo ao que trocamos na ocasião da entrevista. Em relação à ordem de fala, a sequência de temas trazidos pela entrevistada foi reorganizada para se adequar à uma estrutura temática, ajustada às questões mencionadas anteriormente sobre o projeto Não Escrever e aos temas que orbitam em torno dele. No mais, visando também a organização do material, atribuí títulos temáticos os quais irão guiar os blocos de fala de Vidal e meus comentários.

\section{Em Obras: influencia do teatro e o trabalho coletivo}

Paloma Vidal relata sobre a origem do Em Obras, comentando os trabalhos que inspiraram a configuração do projeto. O primeiro, da dramaturga argentina Lola Arias, é o ciclo de performance intitulado Mis Documentos ${ }^{5}$. O segundo é o conceito teatral de biodrama ${ }^{6}$, desenvolvido pela dramaturga também argentina Vivi Tellas. É preciso mencionar que Paloma Vidal nasceu na Argentina e veio ao Brasil com a idade de dois anos, junto com a mãe, em exílio político. Sua relação com o país e com a língua espanhola aparece com recorrência em sua obra, como mostraremos mais adiante na entrevista.

Paloma Vidal (P.V.): O Em Obras, a gente começou no final de 2014. Fui com Diana [Klinger] para a Argentina e a gente viu o Mis Documentos, de Lola Arias: é um projeto incrível dessa dramaturga e

\footnotetext{
${ }^{5}$ Para saber mais sobre o projeto de Lola Arias, acessar o site: http://lolaarias.com/proyectos/mis-documentos-2/?lang=es.

${ }^{6}$ Para saber mais sobre o conceito de biodrama, ver o artigo de Fernando Freitas dos Santos "Biodrama: jogo de tensão entre ficção e realidade”. Disponível em: http://artcontexto.com.br/artigo-fernando_freitas.html.
} 
escritora. Mas é claro que 'palestra performática', tem muita gente que faz. Mas então, a Lola é principalmente do teatro e é alguém que está muito alinhada ao biodrama. Todas essas são inspirações, porque sempre tem essa passagem pela literatura argentina. O biodrama foi um tipo de apresentação criada pela Vivi Tellas, que é também uma dramaturga e que foi quem inventou esse conceito. Na verdade, se trata de uma série de experiências que tem a ver com o teatro autobiográfico, com o teatro documental, que acho que é uma coisa muito do contemporâneo, essa vontade de trabalhar com o documental, com o arquivo. Tem muita coisa feita, no Brasil também, algumas coisas mais interessantes, outras menos. Um dos que vi do Mis documentos era sobre uma moça que contava a história de como tentou conseguir o green card. A gente assistiu esse ciclo e isso era uma coisa que ela sempre faz, assim como a gente faz no Em Obras: três apresentações, ou duas apresentações. Depois de assistirmos, a gente falou: "temos que fazer isso no Brasil, temos que contrabandear!".

Ao refletir sobre suas impressões do que desenvolvem no contexto do Em Obras e sobre o que isso produz a nível coletivo e individual nas participantes, ela comenta que elas fazem "muita catarse nesse trabalho". Esse aspecto parece dialogar com o que ela observa ao afirmar que o Em Obras "é um projeto em que realmente [são] muito felizes", entendendo que "não tem o porquê desconsiderar essa questão da alegria num mundo assim cada vez mais duro", avaliando positivamente a "questão da alegria do encontro." Observamos como para a escritora esse trabalho catártico parece se efetuar por meio da convivência, algo que é marcado pela alegria e que leva à felicidade. Poderemos inclusive sugerir o resgate do sentido aristotélico de felicidade, o de autorrealização, e verificar que essa possibilidade é alcançada no espaço coletivo. Outro aspecto bastante relevante salientado por Vidal é que todas as participantes do Em Obras trabalham com escritas de si, com autoficção e com o gênero documental, como por exemplo ela sublinhará ao sugerir "o perigo de que tudo na vida "vire a Obra". Essa iminência de perigo e a investigação sobre as possibilidades das escritas de si será de fato um dos interesses centrais de Vidal em sua leitura da obra barthesiana, algo sobre o qual comentaremos no terceiro bloco deste material. Pensando sobre o formato do Em Obras, ela traz a noção de "rimas", criada a partir das discussões das participantes e que consistem em uma espécie de eixos temáticos os quais reúnem os trabalhos de todas. Vidal lista alguns exemplos sobre essas rimas:

P.V.: O tema da separação é um tema que aparece em vários trabalhos. E é claro que a gente trabalhou muito com essa ideia do que a gente chama de "rimas": acho que a questão de "se separar", "o fim do amor", isso estava no da Diana [Klinger], no da Ilana [Feldman], no da Elisa [Pessoa]. Depois começou a aparecer muito a questão da maternidade. A Ilana teve um filho, então a última palestra performática dela tem muito a ver com a questão da maternidade. Os da Elisa sempre tiveram a ver, que era uma coisa da filha dela, que foi embora, morava com o pai, fora [do país]. No da Diana agora apareceu também, nesse último que fizemos. No meu sempre tinha essa questão dos meus filhos, fazendo narrações, me acompanhando. Então acho que é um trabalho, uma escrita que, embora cada uma tenha a sua, ela é feita muito nessa conversa, sabe? Inclusive o trabalho da Elisa, que [...] se chamava Cartas do Sul e que eram cartas que ela escrevia para mim, esse procedimento depois entrou no da Diana. [...] A gente trabalhou muito em cima disso, das cartas. [...] Desde o início queríamos que fosse um trabalho coletivo. No caso dessa curadoria da Lola [Arias, de Mis Documentos], ela convida as pessoas, cada um faz o seu. Depois o espectador cria conexões entre eles, porque tem um procedimento em comum, que é essa questão da montagem do texto com a imagem e do autobiográfico. Mas no nosso, sempre teve uma vontade de que houvesse uma circulação de ideias, de que fosse criada uma relação. 
Ainda comentando em geral sobre o Em Obras, Vidal salienta sobre as participantes "o fato de serem todas mulheres”, percebendo que para além dessas rimas temáticas, isso é um elemento forte que as reúne, em como "é relevante pensar que [são] todas mulheres e que [têm] isso em comum". Para ela, não ter nenhum homem dentre as participantes não é um acaso, entendendo que há afinidade no trabalho coletivo das participantes também por isso, por essa afinidade de gênero. Como reflexão final sobre o tema, a escritora destaca que para manter a coletividade, é preciso reiterar-se sempre as questões "o que temos em comum? O que podemos compartilhar? O que nos une?”.

Pensando sobre a forma e o contexto em que se origina o ciclo de palestras performáticas do Em Obras, Vidal aponta para o fato de que tanto ela como Diana Klinger (escritora e amiga com quem tem a primeira ideia do projeto) são do meio acadêmico. Vidal é professora de Teoria Literária na Universidade Federal de São Paulo e Klinger é professora de Teoria Literária na Universidade Federal Fluminense. O ambiente universitário, à princípio, reverbera dentro da própria concepção das apresentações, mas também cumpre um papel de repensar os lugares de encontro na vida acadêmica. Desempenhando os papéis de escritoras, críticas literárias e professoras universitárias, observamos uma semelhança nos papéis desempenhados por Barthes (notadamente discutidos por eles em artigo originalmente publicado na revista Tel Quel em 1971, "Escritores, intelectuais, professores"). Sobre o tema, discutiremos mais na seção dedicada à relação de Vidal com a obra barthesiana. No que concerne ao espaço de encontro no ambiente universitário, a escritora pontua a ocasião do congresso, refletindo:

P.V.: Eu acho que essa ideia do interesse do congresso é muito importante de se pensar. Pensando no Em Obras e em seu surgimento, penso em mim e na Diana. O que quero dizer é que a Diana é alguém cujos livros foram indo assim mais na direção de misturar gêneros, mas ela é principalmente alguém que sempre deu aula, que é uma crítica literária. E eu também, sempre tive muita consciência de que meu lugar é na universidade, dando aula. Então tínhamos muito uma vontade [de manter um vínculo com esse ambiente], diferentemente do projeto que nos inspirou, que é o Mis Documentos [Lola Arias], um projeto teatral, embora as pessoas que participam sejam de fora do mundo artístico, ou não necessariamente, ou ao menos de fora do mundo do teatro. Bem, é preciso de todo modo lembrar que o projeto dela acontece no teatro. E a gente, por outro lado, sempre quis que esse projeto acontecesse prioritariamente no mundo acadêmico. No congresso. Depois fomos descobrindo que ele funciona também em espaços meio híbridos, como por exemplo o Centro de Pesquisa e Formação do Sesc, que é um lugar de palestras, em que circulam pessoas do mundo acadêmico. Quem dá palestras lá são professores que a gente conhece. Mas é isso, pessoas do mundo acadêmico que dão aula lá. Então para gente era muito importante valorizar esse espaço do congresso como um espaço criativo, sabe? Num sentido de que tem que haver algo que acontece com você e com quem está ouvindo. Então entra toda a questão da leitura. A gente lê os textos, os textos são escritos antes. Nós não somos atrizes, não decoramos textos, mas tem toda uma reflexão sobre como ler estes textos, de como realmente pensar em quem está ouvindo, na duração, no ritmo, porque qualquer um que já foi em congresso vê que a pessoa está ali, tem aquele tempo restrito, faz uma coisa cheia de citações que só fazem sentido para você. A gente tem muita dificuldade de entender o espaço como um lugar de compartilhamento e que você tem um público que tem que levar em consideração. Não adianta você fazer sua viagem ali em quinze minutos, ler o seu texto com a cabeça baixa, [no caso de uma comunicação de congresso]. É essa coisa do corpo presente que a gente tem tanta dificuldade de encarar na universidade. [...] Você está ali, presente no congresso. 


\section{Não Escrever: origem e desdobramentos}

Como explicado na apresentação do presente documento, Não Escrever é um projeto que se desdobra em diferentes formatos de expressão. A ideia começa quando Vidal decide investigar o não-escrever de alguns escritores, em contexto acadêmico. Para tal, elabora um projeto de pesquisa no qual investigaria sobre "vários escritores que não escreverem ou que não terminaram [seus projetos de escrita]". Após apresentar o projeto para agências de fomento, recebe o aceite de uma delas e vai à França, em 2015, iniciar sua pesquisa. Ela relata: "quando cheguei lá, na verdade eu já estava nessa deriva mais barthesiana, [...] e decidi fazer nesse formato", de modo que eliminou os outros escritores de seu repertório e concentrou-se em pensar apenas sobre Barthes, aspecto que discutiremos mais adiante. $\mathrm{O}$ projeto inicialmente tinha um cunho mais acadêmico, embora desde o começo, segundo seu relato, houvesse uma intenção de chegar também a um objeto mais artístico (uma de suas intenções era publicar uma coletânea de contos a partir do tema do não-escrever).

Notamos no projeto, de todo modo, que o âmbito criativo ficcional ganha bastante força, quando ela explicita: "o que quero dizer é que o projeto do Não Escrever é uma reflexão sobre a impossibilidade da escrita, mas que não era para virar uma performance. E depois, meio que as coisas se juntaram e comecei a fazer assim”. Observamos que, um projeto que originalmente tinha um propósito determinado, se modifica a partir das experiências artísticas da escritora e, sobretudo, a partir da criação do projeto Em Obras. Ocorre uma contaminação entre os trabalhos desenvolvidos por Vidal em áreas de sua vida que, a priori, não se entrecruzariam tão diretamente: a vida acadêmica e a de escritora. Ela assume que, no final das contas, há uma dificuldade, sobretudo nas áreas das ciências humanas e das artes, de separar o que é estritamente crítica e teoria do que acaba sendo inundado pela criação, pela suposição, pela indagação. Essa reflexão surge quando, em ocasião recente, uma conhecida lhe questiona sobre o fato de ser impossível responder com precisão ao porquê de Barthes não ter escrito Vita Nova. À parte apontar à morte repentina do escritor como justificativa, caberá ao pesquisador e ao crítico sondar e supor o motivo de Barthes não ter conseguido avançar antes em seu projeto de livro, o que será justamente o objeto principal da crítica genética. Se é certo que os documentos de processo nos indicam possíveis caminhos, há certas lacunas que terão de ser preenchidas por previsões, algo que inclusive é caro às outras ciências também. No entanto, sabemos que é parte do esforço científico explorar ao máximo as possibilidades do arquivo com o qual trabalha o pesquisador, de modo que, por ter largo conhecimento deste material, há maior probabilidade de acerto em suas previsões.

Vidal conduz então sua fala para apresentar o histórico de sua produção na época em que começa o Não Escrever. Neste momento, ela confessa sentir que "é difícil saber o que veio antes", mas acaba concluindo que "o que veio antes mesmo [disso tudo do Não Escrever] [era] esse romance que eu estava tentando escrever desde 2013 e que não estava conseguindo achar o jeito”. Percebemos que ao estudar, no âmbito da pesquisa acadêmica, escritores que não lograram escrever, notadamente pensando em Barthes, Vidal desempenha uma busca destinada também ao seu próprio ofício de escritora. Longe de trabalhos separados, ela demonstra que seus dois ofícios são interdependentes, operando em uma espécie de lógica de retroalimentação. Ela assume que foi "entendendo que isso até tinha muito a ver com o Barthes, na leitura que [faz dele]". O fato é que, enquanto ela se empenhava em escrever esse romance, que "é sobre uma família de ricos brasileiros morando no Uruguai", ela prepara e apresenta uma performance em que discute seu não-escrever, já pensando no não-escrever em geral, de outros escritores. Ela considera essa como a Parte 1 de Não Escrever. Ela narra então:

P.V.: Bem, fui para a França e comecei a fazer o projeto [acadêmico Não Escrever], e essa parte de performance também. Então isso será a Parte 2 do Não Escrever, que é o que fiz lá. Tem toda uma história engraçada, porque na verdade comecei a escrever enquanto eu morava na casa da Magali [Nachtergael], 
lá na França. Tudo parece uma grande ficção, não é? Então a Magali virou personagem da performance que eu fazia. Durante 2016, eu fiz essa Parte 2 e tudo, no fim das contas, se chama Não Escrever.

Magali Nachtergael é crítica literária e professora de Literatura francesa dos séculos XX e XXI na Universidade Paris 13. Hospedou Vidal em sua estadia na França, o que possibilitou uma larga troca entre as duas sobre a obra barthesiana. Sobre Nachtergael, ela conta que ela "é barthesiana e tem um monte de livro do Barthes". A influência da francesa é sobretudo importante porque "ela tinha ido ao Japão, o marido dela conseguiu um posto lá! E é aí que o Japão entra no projeto, muito forte". Ela traz "a relação de Barthes com o Japão e o que ele estava procurando por lá". Tudo isso já estaria contemplado na performance da Parte 2 de Não Escrever, que ela escrevia diretamente em francês "com a ajuda de uma das meninas que fazia trio com [elas], uma francesa”. É importante destacar que as performances das Partes 1 e 2 e das performances que ela descreve mais adiante, da Parte 3 e dos Epílogos:

P.V.: [...] são performances diferentes [...]. Os textos são totalmente diferentes, mas os temas são os mesmos: o Barthes e o não-escrever. A estrutura é também sempre meio a mesma, mais ensaística por um lado; por outro, mais autobiográfica; a ficção sempre atravessando tudo, porque sempre tem uns personagens. Acho que o lance desse projeto é essa combinação: autobiografia, ensaio, ficção. Esse é o que comecei a fazer [na Parte 2], que eu fazia muito, sobretudo lá em Paris, porque uns amigos conseguiram um espaço para a gente fazer. E eu sempre fiz no contexto do Em Obras.

Ela enumera outras ocasiões em que apresentou a Parte 2: "sozinha, na universidade de Bordeaux. Depois fiz em Paris, com a Ilana [Feldman] e com a Naruna [Kaplan de Macedo]. E aí depois fiz no Rio, quando voltei, e depois nunca mais fiz". É em seu regresso ao Brasil que começará a fazer a Parte 3 de Não Escrever, "que é esse que está publicado em livro cartonero”, ela explica. Da Parte 3, ela lista as ocasiões em que se apresentou:

P.V.: Fiz a primeira vez na ABRALIC, sozinha, depois fiz dentro do Em Obras, no Sesc [no Centro de Pesquisa e Formação e no Sesc Vila Mariana]. Foram três vezes: em setembro de 2016, quando tinha acabado de voltar, depois em março de 2017, e de novo em setembro de 2017. O que vai acontecendo é isso: depois que fiz no Sesc Vila Mariana, me dei conta que já não tinha mais sentido, eu tinha voltado já fazia um ano da França! Disse para mim mesma: "isso que estou fazendo aqui não me diz mais respeito!".

É neste ponto, em que ela notava que já não lhe fazia mais sentido falar sobre seu retorno, que ela começa "a escrever vários epílogos para esse projeto. Comecei a tentar sair dele". É interessante observar essa vontade de querer "sair" do projeto Não Escrever. Se retomamos seu comentário acerca dos trabalhos das participantes do Em Obras, vemos que está presente em seu trabalho também o tema da "separação", algo sobre o que ela meditará ao afirmar que "a literatura faz muito isso, faz você ter que cortar alguns laços, fazer o luto". Parece haver em seu trabalho artístico, em sua escrita, uma espécie de processo psicanalítico, em que construir a narrativa do problema, do incômodo, é o que permitirá superá-lo, algo que discutem também críticos e especialistas do trauma histórico, notadamente Jeanne-Marie Gagnebin, analisando largamente esse tema em seus ensaios reunidos em Lembrar Escrever Esquecer ${ }^{7}$. Seu esforço em desprender-se do projeto Não Escrever, podemos inclusive estendê-lo para um esforço justamente de superar seu não-escrever, de usar o espaço cênico da performance como um lugar terapêutico, em certa medida, e essa escrita que lhe acompanha, como o resultado do progresso desse trabalho interno. Sobre isso, ela revela que "nenhuma dessas performances, a não ser o livro da cartonera, eu acho que vou publicar. Só que enquanto estava fazendo isso, eu escrevi um livro, que é

\footnotetext{
${ }^{7}$ GAGNEBIN, Jeanne-Marie. Lembrar Escrever Esquecer. São Paulo: Editora 34, 2009.
} 
um diário de viagem [da França]. Acho que esse funciona como um livro". Como fechamento, assim, do projeto Não Escrever, surgem os epílogos, os quais ela intitula Da minha janela e Resistir à Barthes. Vidal sugere que na verdade ambos "poderiam se chamar Não Escrever também. Mas esse último é o verdadeiro epílogo".

Como última questão acerca especificamente de sua experiência com Não Escrever, perguntei-lhe sobre as reações do público às suas performances. Pedi a ela que relatasse, se pudesse, algum episódio que lhe marcou e que sobretudo produziu alguma reflexão em seu processo criativo, ou mesmo uma mudança de condução na performance seguinte. $\mathrm{O}$ objetivo dessa investigação era sustentar que o espaço da performance dentro da totalidade do projeto, além de ser a obra em si, é também uma etapa do processo criativo. Isso se justifica sobretudo quando relembramos o nome do projeto dentro do qual Não Escrever é gestado: Em Obras. Percebemos algo que está em curso de elaboração, que ainda está em criação quando chega ao público, e que participa de um contexto mais amplo, que também está em curso de criação, que é o próprio projeto do Não Escrever, em suas três partes e epílogos. Recolher evidências de que a interação com o público é relevante para o processo criativo da escritora permitirá conceder ao encontro e à performance maior grau de importância. Veremos reverberar a coletividade ao menos em dois aspectos do Em Obras: na concepção dos trabalhos das participantes, apresentações individuais que surgem a partir da troca que têm no coletivo; e da interação com esses espectadores-leitores de suas palestras performáticas, que permite uma colaboração indireta do público com as artistas. Vidal relatará que "em todos esses contextos universitários, sempre tem perguntas depois, então sempre teve muita gente falando muitas coisas. Isso é super interessante”. A escritora sinalizará dois episódios que, segunda ela, são os mais relevantes em termos de contribuição de espectadores-leitores ao seu processo criativo. A primeira ocorreu quando a professora de Literatura hispano-americana na Universidade de São Paulo, Idalia Morejón, "propôs de publicar [a Parte 3 de Não Escrever] na Malha Fina Cartonera. Adorei, achei que tinha tudo a ver. E ela me propôs depois de já ter assistido". Sobre essa publicação, ela avalia que foi o formato ideal e o mais adequado com os temas que articula em seu projeto, sobre a fragilidade do medo da escrita e a escrita como separação, quando afirma que é "adequado ao projeto fazer um livro que tem um suporte muito frágil, que não é um livro que está nas livrarias, e que de alguma maneira isso circula de uma forma mais marginal”. Há claramente um diálogo travado entre a performance em cena e um livro performático. Ambos, palestra performática e livro cartonero, acontecem no registro da efemeridade: a primeira tratando-se de um evento, que inclusive não é registrado em vídeo (comentaremos mais adiante sobre isso), o segundo, pela fragilidade do material, não tem sua durabilidade material garantida como um livro industrial. Ambos são performáticos igualmente por empreenderem um empenho corporal, da presença da artista em cena e do trabalho manual da confecção do livro.

A segunda experiência que relata Vidal de interação com um espectador que resultou em uma modificação em seu processo criativo foi com o tradutor, crítico literário e professor em Teoria Literária na Unicamp Márcio Seligmann-Silva. Ela conta:

P.V.: A dica de fazer a dança veio no dia da apresentação no Sesc Vila Mariana, em outubro de 2017. Uma das pessoas que estavam assistindo naquele dia, que nunca tinha assistido nossas apresentações, era o Márcio Seligmann-Silva, esse professor da Unicamp, que foi meu orientador aqui quando cheguei em São Paulo, uma pessoa muito próxima. Na verdade, naquela performance, eu não chamava as pessoas para dançar. Eu dançava sozinha mesmo. Mas naquele dia, por causa de como era o espaço, eu me aproximava das pessoas, e por isso ele achou que eu estava chamando as pessoas para dançar e que ninguém tinha querido dançar comigo. E aí quando ele comentou isso, eu não falei nada. Eu não quis explicar: "ah, não, na verdade não era para ninguém vir dançar". E então pensei: "tinha que ter feito isso, tinha que ter tirado as pessoas para dançar!". Eu tinha que ter tirado as pessoas para dançar e eu não fazia isso. 
Por fim, Vidal relata sobre como, ao mesmo tempo, há sempre um risco nesta interação com o público, quando o retorno é negativo ou vem em forma de uma crítica abrupta, logo após a apresentação. Ela narra sua experiência:

P.V.: Agora em Nova Iorque [na New York University (NYU)], [estava] um escritor que eu amo inclusive, nesse dia, tinha um monte de pessoas que respeito muito, como a Silvia Molloy, o que foi ótimo - que é o Sergio Chejfec, um escritor do qual já escrevi, um escritor argentino que super admiro. Bem, ele chegou para mim e falou: "ah, foi interessante...". Aquela coisa, do "interessante". A gente entende que a pessoa não gostou. Depois ele falou assim: "é, mas é mais uma leitura possível". É aquela coisa: "interessante, mas, no entanto..." [risos]. Nesse dia da NYU tiveram muitas perguntas. E depois, lá na universidade americana, tem aquela coisa de um pequeno banquete depois. Então além das perguntas, ainda teve esse papo todo.

Acerca desse momento posterior à apresentação, Vidal discorrerá mais largamente em trecho posicionado mais adiante neste documento. Antes de nos emprenharmos nessa questão, no entanto, será preciso compreender de modo mais aprofundado sua relação com a obra barthesiana e como isso motiva não apenas o projeto Não Escrever, senão sua reflexão sobre a escrita em geral.

\section{Sobre o interesse de Paloma Vidal pela obra de Roland Barthes}

O primeiro interesse de Vidal pela obra barthesiana está revelado no título de seu projeto: o nãoescrever. Como descrito anteriormente, em seu projeto de pesquisa apresentado em 2015, ela se interessaria por escritores que tiveram suas escritas interrompidas, ou não conseguiram avançar em seus projetos. Vidal tem um interesse especial pelos textos que Barthes escreveu na última década de vida, período em que ele começava a se aproximar mais da literatura não como um objeto da crítica literária, senão como o desejo dessa escrita. O que a leva à França, então, será essa vontade em investigar seu projeto de livro:

P.V.: [...] o porquê que ele não conseguiu escrever o romance. Claro, tem o motivo mais óbvio, de que ele morreu antes de conseguir. Mas assim, ele estava tentando, durante uns três anos. Digo "tentando", porque a Claudia [Amigo Pino] tem essa leitura de que tudo isso que ele estava escrevendo era o romance: Câmara Clara, O Império dos signos, Roland Barthes por Roland Barthes. Muita gente faz essa leitura e acho que é bem interessante, acho que é isso mesmo. Só que ao mesmo tempo, isso não é um romance, não é? O Câmara Clara, o Incidentes, o próprio seminário [A Preparação do romance], tudo isso poderia vir a ser um romance. Bem, fui me dar conta de que ele tinha encontrado a situação que eu sentia, com a qual me identifiquei, de que era essa a possibilidade que buscava em Barthes. Sabe quando às vezes tem alguma coisa que você não está conseguindo destravar? Acho que no caso dele tem muito a ver com esse medo de se expor, e também o medo dele de finalmente se separar de sua mãe.

Neste trecho, Vidal irá mencionar mais uma colega barthesiana, a pesquisadora e professora de Crítica literária e Literatura francesa na Universidade de São Paulo. Especialista em crítica genética, Pino irá trazer à Vidal um aporte interessante sobre Vita Nova, o projeto de livro de Barthes, como ela comentará no trecho destacado. Todas essas obras citadas pertencem ao intervalo de tempo mencionado, da última década de vida do escritor (1970-80). É interessante observar como Vidal reconhece em parte o logro de Barthes com estas obras, embora de fato não as considere romances. De fato, é localizado um ímpeto ficcional, marcado por um tom ensaístico e por um texto repleto de imagens, sobretudo em Câmara Clara, O Império dos signos e Roland Barthes por Roland Barthes. Os dois últimos, no entanto, também se aproximam bastante do formato de um diário, algo 
que é evidente no outro livro citado, postumamente publicado: Incidentes. No mais, A preparação do romance aparece em dois volumes, um originado das transcrições de suas aulas do curso de mesmo nome, e o outro consistindo em suas anotações de planejamento destas aulas. Às vezes interpretado como um "manual para escrever um romance", o volume para Vidal não se trata em nada disso: "eu fiquei tão fascinada com isso, que alguém resolver preparar seu romance na frente de um público, eu acho isso muito incrível, muito corajoso". Ela explora essa questão quando comenta da obra La préparation de la vie, da escritora Colette Felous. A francesa participou de um dos seminários de Barthes, oferecidos na época em que ele lecionava na École des Hautes Études en Sciences Sociales. Há uma diferença formal entre o "seminário" e o "curso" no sistema universitário francês: o primeiro, trata-se de pequenos grupos, onde há um contato mais próximo entre professor e estudantes; no segundo, são aulas para amplos grupos, normalmente oferecidos em anfiteatros. A preparação do romance será o último curso que ofereceu Barthes, quando professor no Collège de France. Para ela, Barthes era alguém bastante consciente sobre sua presença na sala de aula. Vidal relata:

P.V.: [...] não somos só texto. E o texto é corpo também. E aí é interessante, o Barthes é super interessante para isso, porque ele tinha muita noção disso, da performance, da aula, da voz. São muito performáticos aqueles seminários. O que ele faz antes com o Fragmentos [de um discurso amoroso]. $\mathrm{O}$ que ele gerava nessas aulas. Como ele tinha muita noção do que estava acontecendo ali, no caso dos Fragmentos... do Fragmentos não, do seminário que dá origem ao Fragmentos, o seminário do Discurso amoroso, tinha toda essa questão de que era um grupo pequeno, que tinha uma libido circulando. Eu acabei de ler o livro da Colette Fellous. Esse livro é maravilhoso. O livro dela chama La préparation de la vie. Estou tentando fazer uma mini-pesquisa sobre esses discípulos do Barthes que resolveram escrever sobre ele na primeira pessoa. Essa combinação de biografia com autobiografia e como ele permitiu eles dizerem "eu". Essa era a ideia que eu tinha e essa ideia está no livro explicitada, da Fellous, "ele me permitiu dizer 'eu'". Ela foi uma das alunas desse seminário. Ela diz muito isso, que saía querendo dançar depois da aula, querendo criar, sabe? Toda essa coisa é muito forte, um erotismo das aulas. Tem alguns textos interessantes dessa passagem do formato dos seminários para cursos [...]. Ele tinha muita dificuldade de lidar com esse grande público, [na época] do Collège de France, e daí acho que ele radicaliza, não é? Na verdade, tudo isso [do Não Escrever] surgiu quando eu vi esse livro, quando eu entendi o que era esse livro [A preparação do romance]. [A questão do encontro] é algo que a gente estava falando agora em relação ao próprio Barthes. Como ele gerava esse tipo de relação: o pensamento não acontece sozinho, acontece muito nos cafés, nos encontros. E eu acho que isso sim está muito presente no Em Obras.

Essa permissão do dizer "eu", resgatada no relato de Fellous, Vidal avalia também como um campo de risco. Ela cita o ensaio de Barthes sobre Proust, intitulado "Durante muito tempo, fui dormir cedo". Este ensaio, escrito por ele para uma comunicação em um congresso, surge neste momento em que Barthes buscava acessar uma escrita mais literária, em que sonhava com o romance, com a Obra. Podemos localizar em ensaios e textos desse período referências à Proust, à Stendhal, à Flaubert. Mas é sobretudo em sua fala sobre Proust que Vidal identificará o risco que ela mesma sente correr dentro das escritas de si, da autoficção. Ela narra:

P.V.: [...] fui pra Urt conhecer a casa em que morava Barthes, encontrei com o irmão dele e levei meus meninos. Eles não conhecem [muito sobre Barthes], não sabem direito quem foi ele. Mas fomos lá, vimos o túmulo do Barthes. Claro, eu entendo que não é muito fácil essa fronteira [ficção e biográfico]. Eu mesma tenho muitas críticas e acho que é algo sobre o qual temos de pensar, o lugar do autobiográfico. O Barthes mesmo tinha muitas ressalvas. Eu entendo as ressalvas, eu entendo. [...] Mas é, é uma coisa que a gente deve pensar: quando que o texto, o projeto, o livro, fica muito egocêntrico. 
"Barthes e eu". Lembro de um amigo meu, na época em que eu estava fazendo mestrado. O Barthes tem esse texto, o "Durante muito tempo dormi cedo", em que ele fala que poderia ter dado o título de "Proust e eu". E aí ele fala que na verdade ele não está se colocando no lugar dele. Mas bom, ele era o Roland Barthes. Mas ele está falando. E então, esse meu amigo do mestrado escreveu sua dissertação [com o título] Barthes e eu. E bem, enfim, o pessoal não gostou muito. Porque realmente soa um pouco estranho: "como assim, Barthes e eu?". Na verdade, isso tudo do Não Escrever eu poderia ter chamado de "Barthes e eu". É uma coisa meio delicada, sabe? A história é que não tem o que fazer com isso. Acho que a solução, digamos assim, é como Barthes fala em A Preparação [do romance], a solução é você não reprimir o 'eu'. Qual a palavra que ele usa no começo da Preparação? Tudo bem que ele é o Barthes. [...] Ele fala assim, e esse é tipo o meu lema: [tradução que faz enquanto lê, do francês ${ }^{8}$ ]: "eu acrescentaria que, pessoalmente, sou de uma geração que sofreu demais a censura do sujeito no campo intelectual. Seja pela via positivista, objetividade, o recalque da subjetividade que eram requeridos por exemplo quando se fazia um estudo na Sorbonne (na USP, poderíamos dizer). A história literária, da temporização filológica, que fez as regras da filologia, e que não se pode falar em primeira pessoa. Seja pelas vias, mais tarde, no que me concerne, marxista, que foi tão importante para mim. E eu diria que, mais valem os logros da subjetividade do que as imposturas da objetividade". Então entra nessa, não é? "Vou aqui falar de mim e tudo bem”. É sempre um risco, você sempre pode soar um pouco, não sei, narcisista, egocêntrico. Mas vale mais esse risco do que não se colocar, do que não pensar no que se está fazendo ali.

Vidal reconhece em Barthes um lado corajoso, mencionado anteriormente quando salienta a exposição de alguém que decide preparar seu romance diante de um público, e também pelo risco de assumir o "eu" no discurso. No entanto, é quase paradoxal verificar que nele mesmo ela percebe um lado "medroso". Esse medo estaria sustentado, segundo ela, por diversos fatores, os quais ela elenca trazendo referências. Vidal incorpora esse medo que identifica no escritor em Não Escrever, como relata:

P.V.: Nesse Não Escrever aqui [edição cartonera], tem uma questão do medo; escrevo: "tenho medo de tudo", e termino assim o texto. Acho que fui muito por esse caminho, tentando entender esse medo [de Barthes]. Inclusive, foi muito interessante, porque estava pesquisando essa ideia do medo nele e achei esse texto da Tiphaine Samoyault, que é uma das biógrafas dele. Esse texto dela é incrível, ela começa falando: "eu escrevi essa biografia e uma coisa que nunca entendi é: o que era esse medo de que ele tanto falava que tinha?". Eu coloquei isso na performance, porque é incrível! Ela faz uma lista de tudo que o Barthes tem medo! Ela seleciona isso de todos os textos dele, listando sobre tudo que ele tem medo! Veja aqui, [ela me indica no texto de Samoyault], ela coloca a referência das obras completas, todos os lugares em que ele fala que tem medo. [..] [Ele tem medo] de sua relação com o corpo. É um corpo com medo. Eu falo muito disso, tanto que nessa performance [dos epílogos] do Resistir à Barthes, eu tiro algumas peças de roupas, para marcar o que acho que tem a ver com uma exposição. E junto disso, eu fazia uma espécie de dança. Então exponho aquele corpo meio frágil. Isso porque li uma cena muito engraçada, que agora não lembro mais aonde foi, que numas festas de ano novo, acho que a Marguerite Duras é quem conta, se não me engano. Bem, mas que ela, numa festa de ano novo, ficava querendo tirar ele para dançar e ele ficava com pânico com isso, de dançar com ela, de dançar. Bem, sabemos que a Duras falava que ele não era escritor de verdade porque não encarava as questões mesmo. Não encarava elas assim, sabe? Que é um pouco a minha hipótese também.

\footnotetext{
${ }^{8}$ BARTHES, Roland. La préparation du roman. Paris: Seuil, 2015.
} 
Por simetria, é possível aproximar essa cena de Barthes em pânico de ser tirado para dançar com o comentário de Seligmann-Silva feito à Vidal sobre sua dança em cena, o qual relatamos anteriormente. Duras identifica em Barthes o "medo de tudo" na dança e estende-o para a escrita, acusando-o de não se posicionar de fato nas questões que importam. Poderíamos pensar, do lado de Vidal, que acolher a sugestão de SeligmannSilva de convidar os espectadores da palestra performática para dançar simbolicamente significaria "encarar as questões mesmo". Mais corajoso do que alguém que aceita o convite para dançar é alguém que realiza o convite. Ao aceitar convidar pessoas para dançar com ela em cena, ela se afasta dessa personagem medrosa e, quase que ritualisticamente, assume assim também uma postura corajosa em sua escrita. Assumindo o controle da cena, ela assume também a imagem do "eu", tendo a coragem de se expor na performance. É possível identificar aqui como a separação se realiza novamente: há uma forte aproximação à Barthes e ao mesmo tempo um desconforto em tê-lo como referência. Fica muito evidente, pensando por essa via, o que motiva o título de seu epílogo, Resistir à Barthes. Há um forte índice da sedução, impresso na escrita barthesiana, que ao mesmo tempo representa um impulso, um verdadeiro convite a dizer "eu", um pedido dado no próprio texto de que nos afastemos dele para encontrarmos nossa própria voz. Essa hesitação de aproximação e afastamento de Vidal com a obra barthesiana fica explícita quando ela confessa:

P.V.: Fico tentando ler ele sintomaticamente, com todas as contradições de alguém que ficava, assim, muito querendo se proteger de tudo. Porque relaciono isso tudo muito à Maio de 68. Enfim, a discussão é um pouco assim: Barthes serve para a gente encarar Bolsonaro, por exemplo? É uma pergunta que parece meio idiota, mas o que quero dizer é assim: esse pensamento que é muito do "entre", da "não-confrontação", da quase que "contra-militância", contra o engajamento [...], me faz ficar muito me perguntando politicamente, sabe? Acho às vezes o Barthes pouco engajado e isso é uma questão para mim. Porque super me identifico, por outro lado, como muitas pessoas que encontram o Barthes e ele se torna o pensador de suas vidas. Você fica querendo pensar tudo através dele. E fico achando que ele é medroso demais, sabe? Ele ficou doente durante Maio de 68, ele começou a achar que tinha a ver com a tuberculose. Ele estava acamado, a cidade estava todo explodindo lá fora, e ele doente! Ele morava no centro ali, no olho do furacão. [...] Por isso acho que é uma pergunta a ser feita, quando a gente adota um pensamento para nossa vida, para o que fazemos, para o que pensamos. Acho importante se colocar certas questões. O que [esse pensamento] faz, o que no fim das contas ele consegue. Mas, enfim, acho que só consigo fazer isso porque fica tudo muito no nível da ficção.

A preocupação de Vidal fica neste trecho justificada pela via política. De fato, em Não Escrever - Parte 3, aquele que é publicado em livro cartonero, o desfecho do texto remonta, como já comentamos, ao ambiente político no Brasil no período do conturbado processo de impeachment de 2016. De algum modo, trazer esse elemento para sua narrativa parece funcionar como uma espécie de compensação. Abrindo a possibilidade de ficcionalizar a visita de Barthes ao Brasil, ela se permite atribuir-lhe uma impressão política, ou ao menos abre espaço para se perguntar: o que Barthes teria achado da condução do processo impeachment de 2016? Seu desejo de querer "pensar tudo por ele", pelas ideias barthesianas, talvez lhe faça querer, no espaço de texto no qual Barthes é personagem, associá-lo ao seu próprio posicionamento político, desejando que o escritor partilhasse dele.

\section{A performance participando da escrita: um outro othar para o oficio de escritor}

Como parte final deste documento, foram reunidos os momentos de fala em que Vidal aponta para reflexões mais panorâmicas sobre suas experiências com as palestras performáticas, no Não Escrever e no Em 
Obras como um todo. Em um primeiro momento, veremos como ela posiciona a performance em relação à sua prática de escrita.

P.V.: O que percebo é que tudo isso, no final das contas, começa com essa vontade de escrever um romance. E que aí eu fiquei tentando fazer de vários jeitos e agora estou escrevendo esse livro que espero terminar esse ano $[2019]^{9}[. .$.$] e que no final das contas é o Livro que estava escrevendo na$ minha cabeça esse tempo inteiro, mas não estava saindo. [...] O que começou a acontecer com esse projeto [Não Escrever] - e na verdade, num certo sentido, eu percebo que ele me atrapalha um pouco é que ele tem muitos desdobramentos. Ele mudou muito meu jeito de me relacionar com a literatura, porque não é um projeto de livro, que é o que em geral fazem os escritores. Mas acho que cada vez isso é mais comum: acho que tem tanta crise do mercado editorial, por vários motivos e então, pelo diálogo da literatura com as artes plásticas, pela crise no mercado editorial, por vários motivos de várias ordens, cada vez mais os escritores não fazem um projeto de livro tão fechado. Em geral, pensamos: "Um projeto de um livro. Você vai lá, escreve o livro e então o publica".

É interessante observar um duplo papel, em alguma medida contraditório, da presença da performance na prática da escritora. Por um lado, e como já foi discutido em seções precedentes, o espaço da cena parece funcionar como um espaço terapêutico, em que sua escrita é "destravada". Neste ambiente, ela parece se dar conta deste livro que "estava escrevendo em [sua] cabeça". Assistiremos surgir, então, não uma escrita fruto da performance executada, senão outro produto se formando, outro texto, parte de outro projeto. Em paralelo, como ela relata, a crise do mercado editorial parece de algum modo conduzir o escritor a ocupar espaços de visibilidade pública, de mostrar-se e deixar-se ser visto, tudo a fim de viabilizar uma boa promoção de sua escrita. Sobre essa necessidade de reinventar-se, de criar produções renovadas, Vidal esboça:

P.V.: Acho importante aproveitar um pouco a variedade de suporte que existe hoje em dia. Tinha pensado em publicar o livro junto com alguma coisa que tivesse dentro dele e que levasse para uma plataforma digital, em que todo esse material pudesse estar disponível, sabe? Por exemplo, fico fascinada com essa coisa do Perec, que tinha essa vontade de fazer um hiper livro. Acho que todo escritor tem vontade de fazer isso, mas teria que arrumar alguém para me ajudar. São sempre projetos que tem de ser autofinanciados, porque no final das contas o mercado editorial ainda quer projetos mais convencionais, que tenham mais certeza de um retorno. E todo esse material fica então aí e eu sem saber o que vai dar.

De fato, se de um lado ela atribui à crise no mercado editorial a necessidade de criar uma imagem pública de si, de se colocar em cena, na contracorrente é este próprio mercado que ela identifica como inviabilizador de produções mais ousadas, mais inovadoras. Talvez isso também tenha sido um dos motivos para encontrar total adequação de seu projeto Não Escrever com as edições cartoneras da Malha Fina, além do aspecto, como aponta, "da efemeridade, porque também são poucos exemplares. De fato, é um projeto para mim que não sei o que poderia virar”. Ela reflete então:

P.V.: Acho que nesse tipo de apresentação tem uma aposta de que as coisas vão fazer um sentido ao estarem contíguas. Então, temos: Japão, Magali, não escrever, Uruguai. Sabe, assim? Você vai juntando em torno de uma questão e vendo até que ponto aquilo funciona. E eu não sei se funciona para além

\footnotetext{
${ }^{9}$ No momento de finalização desta entrevista para publicação na presente revista, tivemos notícia da publicação do livro em questão: VIDAL, Paloma. Pré-história. Rio de Janeiro: 7 Letras, 2020.
} 
das apresentações e do sentido que aquilo tinha para mim naquele momento. Tanto que não consegui transformar em livro. O único que transformei em livro foi esse aqui [Não Escrever. São Paulo: Malha Fina Cartonera, 2018], mesmo assim com algumas dúvidas sobre o que estava fazendo.

Descartando a ideia de que o livro cartonero se trataria de um registro da performance, entendendo como uma outra manifestação de um mesmo projeto, o Não Escrever, poderia nos restar um desconforto diante da efemeridade que a palestra performática apresenta. Perguntei à Vidal se em algum momento no Em Obras elas tinham realizado um registro audiovisual ou se teriam já considerado fazê-lo. Ela comenta:

P.V.: Eu sempre fico na dúvida. Acho que tem uma limitação técnica que está envolvida nisso, mas no final das contas acho que tem uma coisa mais sintomática, mesmo. Acho que não filmamos porque acreditamos que não valha a pena filmar. Porque sempre fico pensando que não é possível que depois de todos esses anos fazendo esse projeto não tenhamos um vídeo que dê para assistir. Mas bem, acho que é isso, devemos pensar no que fica, nos desdobramentos que a palestra performática produz.

Sobre esse apelo que faz, de que é preciso pensar nos desdobramentos que são produzidos a partir da experiência em cena, ela discorrerá em outro momento de nossa conversa. Vidal, e de certo modo essa parece ser a postura adotada pelo grupo, há uma aceitação da efemeridade da experiência performática como algo positivo.

P.V.: [Há] uma fugacidade, um momento efêmero, mas que ao mesmo tempo na hora faz muito sentido e depois tem algumas reverberações. A performance, você sempre tem que lidar com esse luto... luto talvez seja um pouco uma palavra forte para isso. Mas no dia seguinte, é um negócio que tem uma duração, acontece, e depois fica uma sensação de: "o que ficou disso?". Você tem que lidar com isso, mas isso é a vida. É sobre ter essa consciência de que aquilo que acontece ali é efêmero. Se formos pensar nas relações amorosas, numa sociedade, toda essa coisa da volta da questão da família, tudo tem a ver com a duração, com a consistência. Num certo sentido, valores que são eternos. Tudo relacionado agora com isso, o tempo inteiro a gente está tendo que pensar nisso. Então o que fazemos vai meio na contramão do que está rolando, do que que se valoriza. $O$ teatro, a performance, sempre lidaram com isso, com o que acaba.

Com essa fala, Vidal revela sua disposição em encarar e se engajar neste universo cênico que não é o seu e entender que nele pode aprender a lidar com algo que identifica na escrita, a separação. Isso ao qual ela a princípio nomeia de "luto" relaciona-se com o espaço terapêutico sugerido anteriormente para o exercício do corpo em performance. Ela avalia, que de fato, é um processo de experimentação, quando diz:

P.V.: Acho que uma coisa a ser levada em consideração sobre esse trabalho é que realmente ele, muito genuinamente, é um trabalho de pessoas que estão experimentando com esse gênero. Então muito do que a gente foi fazendo, fomos descobrindo enquanto fazíamos, entre a gente do Em Obras, o que funciona e o que não funciona. E tem tudo a ver com o que você está falando: "isso aqui funciona, isso não", de ir experimentando no espaço da palestra performática. Agora, na hora mesmo da apresentação, eu acho esse é um ponto que discutimos: o quanto daquilo fica. Eu acho que cada vez mais a gente consegue estar permeável para a situação, para o que está acontecendo ali. Não é fácil para quem não é do teatro, da performance, assumir que você não tem controle sobre o que acontece ali. Mas acho que cada vez mais experimentamos com isso, com o que acontece na hora

Depois de acabada a palestra performática, esse espaço pós-cena é por vezes um lugar de troca com o público. Nos ambientes acadêmicos, por exemplo, Vidal descreve que os organizadores sempre "pedem para ter pergunta. [...] Porque é comum neste ambiente universitário, ninguém termina a palestra, se levanta e vai 
embora. Ao mesmo tempo, não é que nem no teatro". Ela observa que, quando testaram um formato mais próximo ao teatro, "logo em seguida [à apresentação], acho que essa conversa fica um pouco restrita, fazem um comentário ou outro". De todo modo, a palestra performática não é como uma peça, pelo que ela já sinalizou, sobre elas não serem atrizes, não decorarem os textos, mas também por que se no teatro "você agradece, fecha as cortinas e vai embora" na performa "não, a apresentação acaba e você fica ali". Esse "ficar ali" da cena exposta da performance é o convite para a interação com o público, mesmo que isso não fique sempre diretamente indicado como acontece no ambiente universitário.

P.V.: Isso é uma coisa interessante, agora falando com você estou pensando: tem esse espaço do "pós", em que você fica ali, está todo mundo ali, e surgem uns comentários, inclusive alguns desagradáveis. Já aconteceu. É difícil isso, porque depois de apresentar, fica tudo muito à flor da pele, a pessoa chega e começa a fazer uma crítica, é difícil recebê-la na hora, assim que você acabou de fazer. É muito difícil de aguentar o tranco. [...] Mas no geral é muito bom, eu realmente acho que tem uma coisa mesmo de querer sair desse trabalho isolado, que é como você falou: a oportunidade que temos de fazer isso, na academia, é nos congressos e em geral a gente lida com esse momento. [...] Em geral, as pessoas se queixam muito dos congressos. Mas depois se queixam também de que o trabalho fica engavetado. Faz uma tese de doutorado e, quantas vezes a gente não ouve: "ah, vou fazer essa tese de doutorado e depois ninguém vai ler. [...] Para mim isso é muito forte mesmo, essa transformação.

É possível estender essa ideia de transformação observada por Vidal para o que pode ocorrer com o espectador-leitor das palestras performáticas. Por suas palavras, ela percebe que "é algo que costuma ser muito forte. Se [o público] se identifica, acho que é um trabalho que tem uma carga emotiva. Pelas temáticas, por a gente se colocar de uma maneira muito frágil, tratando de temas que em geral tem a ver com separações, com lutos, com questões muito pessoais. Então acho que para o espectador tem uma questão muito forte nesse sentido". Resgatando a ideia que Vidal constrói, trazida anteriormente neste documento, "tem que haver algo que acontece com você e com quem está ouvindo".

Documento editado a partir de conversa com Paloma Vidal, em 17 de setembro de 2019, acerca de seu projeto Não Escrever. 